\title{
The Spaces in Between
}

Before launching into the case studies, this chapter endeavours to offer a review of Indian missions in Berlin. Towards this aim, it addresses state archives safeguarding information on Indians next to the memoirs and private archives of various individuals, asking what kind of knowledge the sources reveal. Once this archival topography is established, I examine the group photographs that the private archives revealed. Apart from giving faces to the people who appear in the book, the photographs also reveal details about their relationships and networks that the archivists cannot 'see'. Originating from private albums once belonging to key actors in the Indian network, the photographs provide important clues to questions about negotiating space.

To understand how the Indian missions established contact with one another, how communists, nationalists, religious activists and secular intellectuals reached out to local actors, how the Germans received them, what they discussed, and how transnational networks were consequently forged between India and Germany, it is important to offset the observations of the Foreign Office against the private papers of the actors concerned. Researchers have consulted the Foreign Office before on the topic of Indians in Berlin, but because their focus was mainly on 'revolutionaries', they failed to examine the files on the Indians' religious activities. It is only when they were examined in relation to one another that the files disclose a fuller picture.

Nonetheless, despite attempting to enlarge the canvas, blank spots of necessity remain. First, the Foreign Office ignored minor players like Inayat Khan's Sufi Lodge and the Hindustan Association of Central Europe. Consequently, we lack an outside perspective of those two organizations. It did not help either that the Nazis destroyed the registry files of the Sufi Lodge and Indian Bureau. All that remains is a notice, added in 1946 to the file on the Sufi Lodge, that this organization was closed in 1933 because of its 'international character' and the many Jews in its ranks. ${ }^{1}$

The private and family archives give insider perspectives on the Indian $\mathrm{Bu}-$ reau, the Hindustan Association of Central Europe, and the Lahore-Ahmadiyya mosque respectively. Although no such archive surfaced from within the Islamische Gemeinde Berlin, we nonetheless have an inside view. This comes from

1 File of the Sufi Lodge of Inayat Khan, 95 VR 4635 (1925-1933). Registry Office BerlinCharlottenburg. 
two famous Jewish converts to Islam, Leopold Weiss (later Muhammad Asad), and Lev Nussimbaum (also known as Esad Bey or Kurban Said), who joined the Gemeinde in the 1920s. Leopold Weiss, a journalist, lived predominantly in the Middle East from where he sent articles on the Muslim world to the Islam Echo, the journal of the Gemeinde, but as far as we know, he never described the Gemeinde itself. ${ }^{2}$ However, Lev Nussimbaum did. Under the pseudonym of Kurban Said, he wrote a novel about an Ottoman princess who arrived in Berlin to study linguistics with the famous German Turcologist Willi Bang but in practice spenther days in the Muslim establishments around Kurfürstendamm. ${ }^{3}$ The princess meets the Khairi brothers who are sitting in a smoke filled den and plotting the Islamic world revolution. She enters the elegant Orient Club with its illustrious visitors, listens to jazz in the Orient restaurant, and visits the coffee house on Uhlandstrasse where the missionary Sadruddin is standing behind the counter. An intimate connoisseur of Muslims in Berlin, and highly sceptical of them at the time of writing, Lev Nussimbaum left us some rare portrayals of the Indian actors who will be introduced in this chapter.

Viewed together, all these sources convey to us how the Indian missions in Berlin communicated and, through these, how the network as was wrought. The chapter forms a prelude to the case studies which continue to illustrate that (and why) Jews were among the missions' most active members.

\section{A Survey of Indian Missions in Weimar Berlin}

The Indians in Berlin during the interwar years left a broad paper trail, not least because the Germans kept a close watch on their activities. The German Foreign Office is a leading source.

First, initial attention focused on the Indian insurgents who in the First World War made up part of the Indian National Committee, which the wartime German government funded and directed. During the war, with German support and with a view to revolutionizing the masses in India, the committee acquired the backing of $5^{6}$ Hindustani (Hindu and Muslim) aristocrats. ${ }^{4}$

2 A narrative of their conversion to Islam can be found in Jonker, The Ahmadiyya Quest, 141-4; Reiss, The Orientalist; Günther Windhager, Leopold Weiss alias Muhammad Asad: Von Galicien nach Arabien 1900-1927 (Vienna: Böhlau, 2002).

3 Kurban Said, The Girl from the Golden Horn (New York: Barnes \& Nobel, 2001). Originally published as Das Mädchen vom Goldenen Horn (Vienna: Zinnen-Verlag, 1938).

4 Heike Liebau (2010) “Unternehmungen und Aufwiegelungen”: Unabhängigkeitskomitee in den Akten des Politischen Archivs des Auswärtigen Amts (1914-1920)', Archival Reflexicon. www.projekt-mida; Franziska Roy, Heike Liebau and Ravi Ahuja (eds) 'When the War Began 
However, when left stranded in Berlin, most of these insurgents then turned to Moscow for a new political opportunity to continue serving the cause of the Indian people. The Russians co-opted M.N. Roy, a prominent committee member and the first to be accepted into the Russian Communist Party, and sent him to Tashkent where, in 1920, the Communist Party of India was founded. ${ }^{5}$ Other committee members, among them Moulvi Barakatullah, Muhammed Umar, the brothers Abdul Jabbar and Abdul Sattar Khairi, V. Chattopadhyaya and Tarachand Roy, travelled to Moscow in 1921 to see if and how the Russians could help them fulfil their aims. ${ }^{6}$ In the end, though, they remained in Berlin and took advantage of the fact that the city was outside the British Empire to launch their political activities.

Second, the Foreign Office also kept close track of the transnational organizations that followed suit. In 1921, V. Chattopadhyaya set up the Indian Bureau as a transnational platform between India and Germany. ${ }^{7}$ Under his leadership, it provided a meeting place for other committee members, offered help to students arriving daily from India, commissioned translations and reached out to German industries in search of a foothold in India. When the Third International, the Soviet Union's brainchild to bring other countries into the communist struggle, decided to move headquarters to Berlin, the Indian Bureau was incorporated into the city's sprawling communist network. ${ }^{8}$

Third, diplomats kept a watch on the activities of Abdul Jabbar and Abdul Sattar Khairi, two members of the Indian National Committee who embraced pan-Islamism through setting up the Berlin Islamic Community (Islamische Gemeinde Berlin) in $1923 .{ }^{9}$ The place and time were well chosen for that. Not only from India but from every corner of the Muslim world, students flocked to Berlin. In fact, in the interwar period, Berlin became the main meeting place to prepare for independence outside the empire. Rallying for the organization during the Eid festival of 1923, Abdul Jabbar Khairi claimed to have gathered as many as 45 Muslim 'nations' under its roof, not to mention the German and other European Muslims. It was an important international moment, which,

We Heard of Several Kings': South Asian Prisoners in World War I Germany (New Delhi: Social Science Press, 2011), 106.

5 Kris Manjapra, M.N. Roy: Marxism and Colonial Cosmopolitanism (London: Routledge, 2010).

6 Nirode K. Barooah, Chatto: The Life and Times of an Indian anti-Imperialist in Europe (Oxford: Oxford University Press, 2004).

7 AA PA R 77.461 (1921-1926).

8 AA PA R 31.707 (1922-1930); Barooah, Chatto.

9 AA PA R 78.240 (1924-1928); R 85.281 (1926-1934); R 78.241 (1929-1931); R 78.242 (1932-1936); R 10.4801 (1936-1939). 
Khairi asserted, would not only raise awareness among the Indian masses but would also revolutionize the entire Muslim community across the globe. ${ }^{10}$

Fourth, when Ahmadiyya missionaries from Lahore arrived in Berlin in April 1923, diplomats opened a new file on the newcomers, which they labelled 'Churches and Religious Communities: Islam."1 This is to say that, since Ahmadiyya missionaries did not engage in any political activities, they were assigned to the 'Church' section. In his very first letter to the Foreign Office, Sadruddin came straight to the point by writing, 'I have enough money with me for the erection of a mosque which I must quickly set up here, for the Muslims here have no church to attend. ${ }^{12}$ German civil servants, for their part, were quick to establish that the Lahore-Ahmadiyya Movement, although a Muslim sect, seemed to be a peaceful organization that fitted in well with German intentions to create a harmonious, democratic society. Ahmadiyya, the reports said, had abolished jihad as war and instead laid emphasis on efforts to civilize oneself. When the Germans also discovered that Ahmadiyya missionaries told Muslims to obey existing governments, whether Muslim or otherwise, they found them an attractive plot on the outskirts of Berlin-Wilmersdorf on which to build. Soon, the dome of the first mosque that Berlin had ever witnessed appeared over the treetops of Fehrbelliner Platz. Six years after it had opened its doors, the missionaries founded a suborganization through which to express the intensive Muslim-German networking in which they engaged, namely the German-Muslim Society (Deutsch-Moslemische Gesellschaft). ${ }^{13}$

Fifth, one Indian organization to escape diplomatic scrutiny was the Hindustan Association of Central Europe (Verein der Inder in Zentraleuropa). Founded in 1923 by Zakir Husain, it offered an academic rather than a political forum. Seeing Hindus and Muslims as equal members of a future Indian state, it kept its distance from the high-flying missions of the other three such organizations. The association was mainly occupied with engaging in an intellectual encounter with German society and translating key concepts from one cultural tradition to the other. ${ }^{14}$ On arriving in Berlin, Zakir Husain made sure that Gandhi's most recent speeches were translated into German and his friend Abid Hussain translated the literature on Germany's latest pedagogical reforms into Urdu. Their mutual friend Gerda Philipsborn took those ideas to

\footnotetext{
$10 \quad$ Register Office VR B Rep. 042/Nr 26590 (1922-1955).

11 AA PA R 77.456 (1923). Politik Indien 16/Kirchen und Religionsgemeinschaften: Islam.

12 AA PA R 77.456 (5 March 1923).

13 AA PA R 78.241 (1928-31); Jonker, The Ahmadiyya Quest, 63-76.

14 Razak Khan, The German Connection: Actors, Institutions, Networks, and the Reformation of Modern South Asian Islam. Special issue of Comparative Studies of South Asia, Africa, and the Middle East (CSSAAME), forthcoming 2021.
} 
India where she set up a Waldorf kindergarten at the Jamia Millia Islamia university. Another feature of the Hindustan Association was that it sought a separation between religion and the nation, in this case the Indian nation. This did not mean that it turned its back on religion; on the contrary, its suborganization, the Association of Urdu Students assigned its Muslim members a private space in which to engage in Muslim festivals. ${ }^{15}$ Photographs of these gatherings betray its active role in getting Germans, Indians, Jews and Muslims around the same table.

Sixth, and last, the other mission to remain under the radar was the Sufi Lodge, initiated in 1925 by the musical genius Inayat Khan (1882-1927), himself descended from a long line of Sufi masters in the Punjab and the founder of Universal Sufism. According to the scant evidence available in the registry office, the lodge recruited well-to-do Germans into its ranks who, after Khan's death, appointed the Persian Hossein Kazemzadeh Iranschär (1884-1962), a revolutionary and a member of the Persian National Committee in Berlin during the First World War, as their Sufi master. ${ }^{16}$ When the Sufi Lodge closed down in 1933, both master and pupils joined the Ahmadiyya mosque.

This then is the list of Indian missions in Berlin, as seen through the lens of the state archives and beyond. However, much more was going on behind the scenes. In June 1924, for instance, diplomats noted that the Indian Bureau had folded because of 'lack of money', which a letter from Chatto himself, stating that another Indian organization in Berlin-Halensee had taken over the work, corroborated. ${ }^{17}$ The previous year, British Intelligence discovered that a certain Hindustan Association had purchased a new clubhouse near Halensee and, on the Berlin Foreign Office's recommendation, had given the lease to Chatto. British Intelligence also asked the Germans what measures they intended to take. ${ }^{18}$ For state security reasons, German diplomats kept their silence. After all, the British had barred German industry from India, a punishing measure that deeply hurt the German economy. ${ }^{19}$ The Indian Bureau, however, was forging a whole new web of relationships between Germans and Indians, one that pointed to a promising future together.

There is still a footnote to this. In 1924, German Buddhists set up the Buddhist House in Berlin-Frohnau. There were already pre-existing ties with Theravada Buddhism in Ceylon and some German Buddhists had already travelled

\footnotetext{
15 Private Hamied archive, Mumbai, File Do2015-11-01 (1925-1927), examples 34 and 50.

16 Berlin-Charlottenburg registry office, 94 VR 4635.

17 AA PA R 77.461 (10 June 1924).

18 AA PA R 77.461 (25 August 1923).

19 AA PA R 30.615 (1921-1926).
} 
to the island to set up their own Buddhist convent. The Ahmadiyya mosque and the Buddhist House were in regular communication. ${ }^{20}$ In the eyes of the Berlin public, the Buddhist House counted as yet another Indian mission. Until 1954, however, when the newly founded state of Sri Lanka set up the 'Buddhist Mission to Germany', it remained a purely German enterprise.

\section{$2 \quad$ Experimenting with Indian Secularism}

With this archival material at hand, it becomes possible to enquire into the nature of the network that Indian intellectuals created in Berlin. For a start, they arrived in the city with a religious and cultural self-understanding in their luggage that differed from that of other Muslims. Having grown up in multireligious India around 1900, Indians were still familiar with the practice of pluralism that had once been what Dumont called 'the cement of Mughal power', and that continued to exist under British rule, although in ways that had become much more precarious. ${ }^{21}$ Drawing from that self-understanding, Indian intellectuals took great care to establish relations with a large range of groups. In the previous chapter, I explained how they merged with the transnational Muslim community, which was in the process of creating its own religious infrastructure. In this chapter, I shall show how the Indians cultivated ties among themselves - Muslims with Hindus, and Ahmadiyya missionaries with devout communists. As the case studies demonstrate, the Indians also wove a web of relations with Europeans. At this point in the text, it is noted that Muslim Indians in Berlin created spaces for encounters that differed from those of other Muslim organizations and explicitly drew in non-Muslims.

Surely, Egyptians, Persians and Turks also brought their experiences of interreligious coexistence in their luggage, ${ }^{22}$ but the ways in which Indians reached out to Christians and Jews in Berlin was not always understood. Some

20 Bhikkhu Bhodi, Promoting Buddhism in Europe. www.BuddhaSasana (200o); Paul Dahlke, 'Unser Haus', in Paul Dahlke et al. (1926) Die Brockensammlung: Zeitschrift für angewandten Buddhismus (Berlin-Frohnau: New Buddhist Publishing House), 4-6, 89-93; Hellmuth Hecker, Lebensbilder deutscher Buddhisten: Ein Bio-Bibliographisches Handbuch. Vol. I: Die Gründer (1990) and Vol. II: Die Nachfolger (1992) (Konstanz: Universität Konstanz); Gerdien Jonker, 'Das Archiv des Buddhistischen Hauses in Berlin-Frohnau'. Projekt-Mida.de/reflexicon (2019). It is interesting to note that Jewish interest in Budt dhism was considerable. See Sebastian Musch, Jewish Responses to Buddhism in German Culture, 1890-1940 (London: Routledge, forthcoming, 2019).

21 Bigelow, Sharing the Sacred; Louis Dumont, 'Nationalism and communalism', in Louis Dumont, Religion, Politics and History in India (Paris: Mouton, 1970) 30-70.

22 Albera and Couroucli, Sharing Sacred Spaces in the Mediterranean. 
Muslims in Berlin even viewed Indian practices of inclusion with abhorrence. In 1924, for instance, the Egyptian political activist Mansur Rifat fumed against the Ahmadiyya missionaries with whom he shared the Berlin space. Scolding the founder of the Ahmadiyya movement for being 'crazy' and 'paranoid', Rifat thought he had proof that Ahmadis 'now cunningly and sneakily shelter themselves under the most vicious and false accusations of the Moslems by appealing to the Christians and Jews.' ${ }^{23}$

The bone of contention, or so it seems, was the Ahmadiyya community's declared loyalty to the British, a loyalty that Arabs, especially Egyptians, abhorred. In one of his many political pamphlets, Rifat noted that 'Muslims connect the idea of bloody wars with the coming of Mahdi, as he shall kill all Christians and Jews and extend the religion of Islam with the sword and spare no one who shall not accept Islam, ${ }^{24}$ By this, Rifat meant that the struggle for political independence would not halt in the face of violence and that the British better beware. England was the enemy, and Muslims who tried to puncture that image of the enemy were clearly suspect. In this contested field, the transnational Muslim community in Berlin often pitted political perceptions of the freedom struggle against the equally political practice of inclusion. As was explained in the previous chapter, it took all the mediation skills that some of the Muslim actors could muster to keep the community together.

When considering the Indian missions in Berlin in their entirety - there were six plus two suborganizations - a different interpretation becomes possible. There were three Muslim missions (if one counts Mubarak Ali's aborted attempt to build a mosque on behalf of Ahmadiyya-Qadiani, their number rises to four), two Hindu-Muslim political associations and one academic organization. Thus, operating with the language and symbols of politics, a portion of the Indian National Committee crew who remained in Berlin after the war, the revolutionary Indian Bureau, and the much more moderate Hindustan Association of Central Europe joined hands to create a shared secular space in which German and European communists collaborated with the Indians. Operating with the language and symbols of religion, by contrast, Jabbar Khairi's pan-Islamist movement, which he lodged in the Berlin Islamic Community, the Lahore-Ahmadiyya mission, and the Sufi Lodge of Inayat Khan,

23 Mansur Rifat, Total Demoralisation of the Ahmadiyya Sect: Further Evidence in Regard to their Activities as British Agents and Menace to Islam (Pamphlet No. III) (Berlin: Morgenund Abendland-Verlag, 1924) 1, 5. The complete collection of Rifat's pamphlets can still be found in the Staatsbibliothek in Berlin.

24 Rifat, Total Demoralisation, 5. 
each created a shared religious space in which Germans and Europeans were heartily welcomed.

In the religious milieu, the Indian activists and members of the German life reform movement shared knowledge and engaged in social exchanges. In the political milieu, Indian activism became fused with European communism. Notwithstanding their considerable differences, the two worlds interacted with each other at different levels. In hindsight, it seemed odd that communists should have cooperated with religious believers and vice versa. However, all Indians shared a common background and fields of social experience, which they brought to a new level through their perception of 'Hindustan' as a model for Indian secularism.

The Indian perception of secularism is neither the separation of church and state nor the development of private forms of religion, as in Europe. ${ }^{25}$ Drawing on Ashis Nandi, Anna Bigelow described it as the equality of distribution of state services to all religious communities and equal representation and respect in the public sphere. ${ }^{26}$ Indian secularism, she holds, builds on the received knowledge that, for the last 500 years, Hindus, Sikhs, Jains, Jews and Muslims learned to maintain a religious equilibrium through creating shared religious spaces. Often starting from the tomb of a local Muslim saint, India's inhabitants developed practices of pluralism, using storytelling, symbolic gestures, and local politics as their instruments. Bigelow outlines the creation of shared spaces as a process through which each religious group adds its own achievements and, through those, holds its own stakes. In that manner, shared spaces were able to grow into 'key sites of the town's moral past', conveying to the inhabitants who they were and, consequently, how to navigate a shared future. ${ }^{27}$

In the 1920s, Indians were aware that shared spaces were delicate structures that needed the support of those in power. It is therefore conceivable that the Indians in Berlin adopted the idea of secular practices as a way of stabilizing and guiding India's pluralism. Viewed from that angle, the behavioural practices they encountered and the spaces they created fused to offer a new airing

25 Talal Asad, Genealogies of Religion (Baltimore: John Hopkins University Press, 1993); Peter L. Berger (ed.) The Desecularization of the World: Resurgent Religion and World Politics (Michigan: William B. Eerdmans Publishing Company, 1999); Grace Davie, Europe: The Exceptional Case. Parameters of Faith in the Modern World (London: Darton, Longman and Todd, 2002).

26 Bigelow, Sharing the Sacred, 5 .

27 Bigelow, Sharing the Sacred, 7. 
of the old received wisdom that one should share one's space with others, whoever those others might be. ${ }^{28}$

\section{$3 \quad$ Glimpses from Private Archives}

A word about the difference between state and private archives is perhaps again appropriate. State archives reflect governmental and administrative views and interests. They store the stream of the day-to-day decisions that are made when civil servants administer the law. In effect, they constitute the country's political memory. Whether through border controls, diplomatic observations, police actions or changes in a person's civil status, individuals are captured in that memory whenever their actions coincide with the routine work of the state.

Private archives, by contrast, arise from emotional bonds. ${ }^{29}$ During their lifetime, individuals amass birth certificates, school reports, diaries, letters, manuscripts, photograph albums, books with inscriptions and stacks of crumbling musical notes - things that pertain to particular stages of their lives and that convey their emotions. Most private archives deliberately emphasize the cherished occasions, leaving aside the less pleasing aspects of a person's life. Often enough they include a random collection of things that had been stored away in cupboards or at the backs of drawers and had remained there for years on end. Once the owner dies, their continuation becomes fragile. Unless steps are taken to safeguard these memories, the objects in which they are embedded are usually thrown away.

Of course, exceptions occur. When people grow into public figures, their private archives provide a basis for memoirs and biographies. Such was the case with Khwaja Abdul Hamied, who studied in Berlin in the 1920s. He moved in and out of the Hindustan and Urdu associations, the Indian Bureau and the Ahmadiyya mosque, only to return to India with a well stitched up Jewish

28 Many of the Ahmadiyya mosque's early publications associate 'democracy' with every participant being allowed to have his or her say and being listened to. See Jonker, The Ahmadiyya Quest, 119-25. Later in his life, one visitor to the mosque, Khwaja Abdul Hamied, recaptured his thoughts on sharing space in several publications, including K.A. Hamied, What is Hindi? (Bombay: Alisons \& Company, 1956); and Khwaja Abdul Hamied, A Life to Remember: An Autobiography (Bombay: Lalvani Press, 1972).

29 Ann Cvetkovich, An Archive of Feelings: Trauma, Sexuality, and Lesbian Public Cultures (Durham: Duke University Press, 2003). 
network that changed both his career and his private life. Hamied's memoirs explain how all that came to pass. ${ }^{30}$

The personal archives of some of the Indian and German students in Berlin at the time reveal that there were others among Hamied's circle of friends whose recollections have attracted attention. Zakir Husain, who became the fifth president of independent India, has been honoured with several biographies. ${ }^{31}$ The life of Gerda Philipsborn, the German Jewish singer who befriended Zakir Husain and followed him to India, was lovingly portrayed after her untimely death. ${ }^{32}$ Indian ornithologist Salim Ali wrote an intriguing account of his career as India's first bird man. ${ }^{33}$ Muhammad Asad described his journey from being the heir to a dynasty of rabbis in Galicia to becoming a Muslim scholar in Lahore. ${ }^{34}$ Barely a trace remains of the Ahmadiyya intellectuals Sadruddin and F.K. Khan Durrani, ${ }^{35}$ though Dr Sheikh Abdullah, the third imam in the Ahmadiyya mosque, is remembered in an impressive collection of obituaries. ${ }^{36}$ Writing was not the only medium through which to keep memories alive. Lisa Oettinger, one of the first female artists to enter the art academy in Berlin, launched headlong into a cosmopolitan lifestyle by marrying the assistant imam of the Ahmadiyya mosque, Azeez Ur-Rahman Mirza. Later in her life, she bequeathed two trunks full of annotated objects to her son explaining that he was heir not to one, but to two cultures - her own German Jewish heritage and his father's Mughal one.

What one sees time and time again in the photographs is that couples were marrying across religious divides, in this case the one between Muslims and Jews. The general German enthusiasm for such marriages has attracted little scholarly attention. Kris Manjapra mentions a number of mixed couples in

$30 \quad$ Khwaja Abdul Hamied, A Life to Remember: An Autobiography (Bombay: Lalvani Press, 1972).

31 Ziaul Hassan Faruqui, Dr Zakir Hussain: Quest for Truth (New Delhi: S.B. Nangia, 1999); M. Mujeeb, Dr Zakir Husain: A Biography (New Delhi: National Book Trust, 1972); A.G. Noorani, President Zakir Husain: A Quest for Excellence (Bombay: Popular Prakashan, 1967); Ali B. Sheikh, Zakir Husain: Life and Times (Delhi: Zakir Books, 1991). Anita Kashap, 'Gerda Philipsborn: obituary', The Jewish Advocate, Delhi, 1943. Reprinted in Gene Dannen, 'A Physicist's Lost Love: Leo Szilard and Gerda Philipsborn'. www.dannen .com/lostlove. 26 January 2015.

34 Muhammad Asad, The Road to Mecca (New York: Simon \& Schuster, 1954).

35 Jonker, Ahmadiyya Quest, 54-7.

36 Mahmudah Abdullah, 'My loving husband', in Anon., 'Obituary: Dr Abdullah Shaikh Muhammad', The Light, 35 (special issue) 1956, 26 August, 6-7. 
passing. ${ }^{37}$ In his outstanding work on interwar Paris, Michael Goebel records the number of French colonial marriages that took place in that city and noted that 5000 of the 60,000 North Africans living there entered into liaisons with French women, but that fewer than 700 actually married them..$^{38}$ Both authors regard cross-cultural relationships as mere outlets for sex and love. Such things happen, they seem to imply, but do not really have much to do with global networking. In Germany, however, it was by no means a trivial phenomenon. Rather, marrying across cultural and religious divides seems to have been a stable feature of the kind of cosmopolitics in which Germans engaged. Especially among the bourgeois and fashionable classes in Germany and India, marrying outside one's cultural and religious world was believed to be an enabling means of connecting 'East and West', perpetuating a network of familial relationships that outlasted the marriage partners' lives. Ahmadiyya missionaries in Berlin catered to this trend by offering legal advice and preparing the necessary paperwork that allowed couples to enter the union. ${ }^{39}$ Of course, Indians and Germans, Hindus and Muslims, Christians and Jews constituted categories that could not be discarded, but by turning themselves into 'citizens of the world', as some of their gravestones remind us, ${ }^{40}$ the partners tried very hard to overcome them.

\section{The Visual Archive}

Emilia Oettinger and her daughters Lisa and Susanna, Azeez Ur-Rahman Mirza, S.M. Abdullah, Khwaja Abdul Hamied, and Luba Derczanska are only some of those who engaged in the encounter between Jews and Muslims in the interwar period. We are familiar with their faces from photographs of the Ahmadiyya community, farewells at train stations, meetings with important visitors, private and public Eid festivals, student gatherings, lectures in the Ahmadiyya mosque, sports events and outings. Being the heyday of photography, hundreds of photographs to document events have made their way into dozens of photograph albums.

37 Kris Manjapra, Age of Entanglement: German and Indian Intellectuals across Empire (Cambridge: Harvard University Press, 2014), 97.

38 Goebel, Anti-Imperial Metropolis, 91.

39 The mosque archive in Berlin contained hundreds of documents on mixed marriages.

40 As in Woking's Muslim Burial Ground at Brookwood Cemetery, Woking (UK), among others. 
Some of these photograph albums have resurfaced in recent years. I stumbled across six in the possession of Lisa Oettinger's son ${ }^{41}$ and four more had survived in the mosque archive that seem to have belonged to Imam Abdullah and another was found among the possessions of Khwaja Abdul Hamied's children. In all, 11 albums and several loose photographs came to light. The Oettinger and Abdullah albums contain snapshots of life in and around the Ahmadiyya mosque - they show community gatherings, Eid festivals, evening lectures, afternoon teas, garden parties, tennis matches, and eager guests congregating around food-laden tables. The viewer can see Indian men and German women who are obviously couples and, looking at their faces in the photographs, it soon becomes apparent that such couples sought out each other's company: they form joyous little bands of friends whose stories await discovery. Likewise, the Hamied album provides snapshots of life in the Hindustan Association of Central Europe, with faces around the table at an Eid festival then reappearing in group photos marking some important event.

When such albums come to light, they typically confront the viewer with an array of family members, friends and cherished acquaintances. The owners of the albums usually selected the photographs long after they had been taken, placed them in chronological order and inked in half-forgotten names on the side to keep the memory alive. The resultant gallery of personal highlights is an illustration of the owners' narratives about themselves, their contemporaries and their circumstances. For us, who have no access to that memory, such albums merely function as a spotlight on an otherwise lost past, encircling significant moments of personal encounter and leaving everything else homesickness, misery, enemies, foes - in the dark. Still, there remains a lot to see and a survey of the group photographs that are scattered among the pages drives home the obvious point, namely that many more actors were engaged in the network than those we know by name.

At this point, I present a handful of these photographs for examination. I selected the first because most of the dramatis personae are listed on the side, thus providing an important means of identifying not only the people in the photograph, but also those in other photographs that I chose because they showed odd combinations of actors, albeit presumably not odd to the actors themselves. However, for us born later in time, depending on what the written sources tell us, seeing these faces side by side may come as a revelation. This is because the photographs prove not only that the Hindustan Association was in communication with both the Indian Bureau and the Lahore-Ahmadiyya community, but also that they show how the Ahmadiyya missionaries went about

41 Jonker, 'Lisa's things', 279-310. 


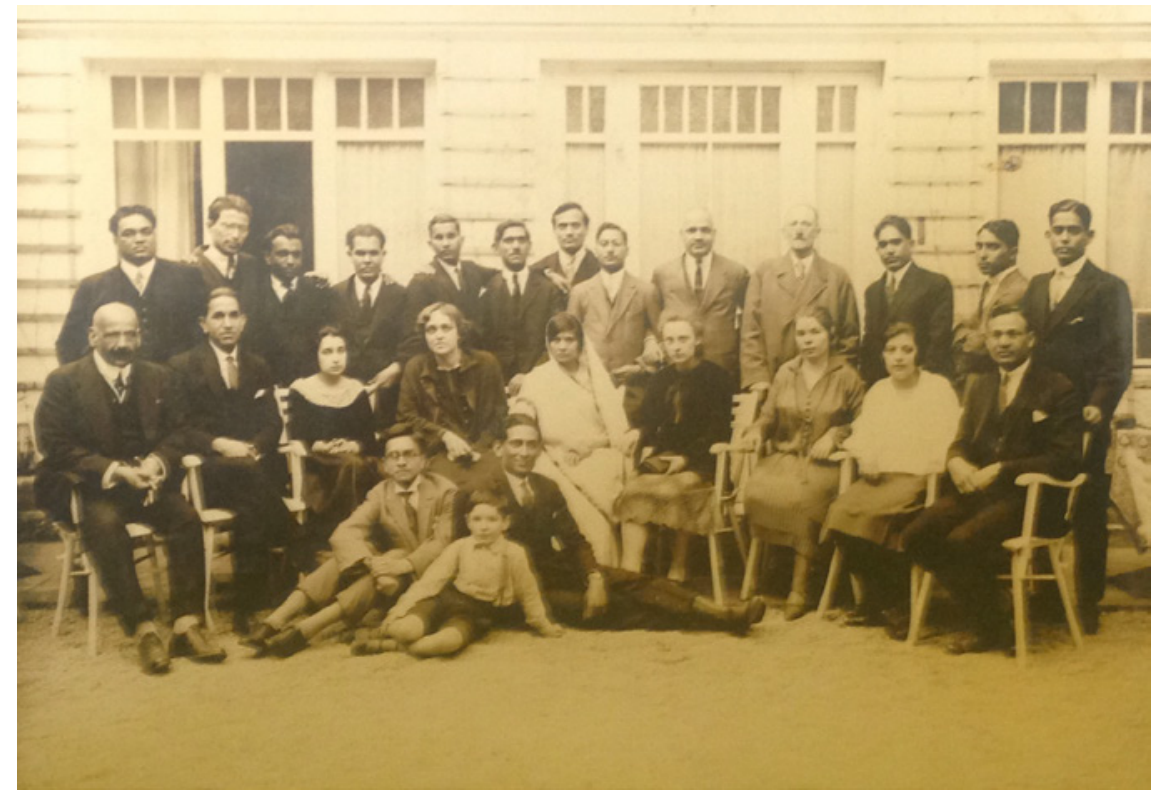

FIGURE 2.1 The Indian Bureau, c.1925

establishing their contacts and, once established, how far those networks reached.

When Zakir Husain left Berlin in 1926 to join the Jamia Millia Islamia (National Islamic University) in Delhi, the Hindustan Association of Central Europe, of which he had been the founder, could not have helped but feel the void; at least, filing through Hamied's private photograph collection gives that impression. The album, which depicts Hamied's very own 'Berlin' moment, starts with pictures of his sea passage from Bombay to Trieste before moving on to his first room in Berlin, his first love, Luba, and his friends from the NonCooperation Movement days in Aligarh, Zakir Husain, Abid Hussain and $\mathrm{Mu}-$ hammad Mujeeb. We see him on boat tours, enjoying picnics and with his fellow students in the laboratory. In the early group of photographs Hamied is still one of many. It is only when Zakir Husain left Berlin and Tarachand Roy took over as president of the Hindustan Association of Central Europe that he gradually moved centre stage. ${ }^{42}$

In September 1926, Hamied took the initiative and, as he describes in his memoir, organized that year's Eid festival, to which 'I invited some important

42 The photograph album in the private Hamied archive has 34 pages and 117 photographs. 
people and friends living in Berlin. ${ }^{43}$ His memoir includes a photograph of that event, which shows a number of men and women, both Indian and European, sitting around a festive table. In his private album, however, this photograph is followed by the one printed above, which shows the same group of people, this time with their names recorded on the side (Figure 2.1) ${ }^{44}$ The text around the photograph reads as follows:

Standing left to right: Mr Muhammed Umar, Mehdi Hasan, Mr Nambiar, ?, ?, Mr Chattopadhyaya, ?, ?, Professor Tarachand (Roy), ?, Mr Shahidi, Rauf Malik.

Sitting left to right: ?, Dr Hamied, Fräulein Luba, Nizamuddin, ?, ?, Agnes Smedley the famous communist, Mrs Surasini, Mrs Shahidi, Mrs Jacob, Mrs P/Frada, Barkat Ali.

With respect to his reference to 'important people and friends', we know that Nizamuddin and Shahidi were Hamied's closest friends and that his fiancée Luba befriended the communist women Mrs Jacob and the P/Frada sisters Sonia and Dunia. We also know that Mr Shahidi had married a well-known convert who in the Lahore-Ahmadiyya mosque was known as Hildegard Rahel Scharf. ${ }^{45}$ This then was his circle of friends - Indian Muslim men and their non-Muslim European spouses - whom he invited to celebrate Eid (only Nizamuddin's fiancée, Estusia Tenenbaum is missing from the picture).

Hamied doubtlessly counted V. Chattopadhyaya as among these 'important people', describing him as 'a brilliant man' and 'very well-known among the official circles in Berlin'.46 In the photograph, he is standing behind his lover Agnes Smedley and his sister Surasini. The latter married his closest ally, the journalist A.C.N. Nambiar who, after the war, became Indian ambassador in Bonn. As we know from the biographies of German communists who worked for Chatto, this quartet made up the inner core of the Indian Bureau, of which Chatto was the 'soul'. ${ }^{47}$ Many Indians came and went, the biographers relate, but the paid officers were all European communists, men like Louis Gibarti

43 Khwaja Abdul Hamied, A Life to Remember: An Autobiography (Bombay: Lalvani Press, 1972), 55 .

44 Private Hamied archive, photograph album, 22-3. The question marks are his.

45 Hildegard Scharf, Irma Gohl and Huda J. Schneider, 'Drei Europäerinnen bekennen sich zum Islam', Moslemische Revue, 1 (1931), 53-9.

46 Hamied, A Life to Remember, 35.

47 Margarete Buber-Neumann, Von Potsdam nach Moskau: Stationen eines Irrwegs (Cologne: Edition Hohenheim, 1981), 93-106; Babette Gross, Willy Münzenberg, eine politische Biographie (Frankfurt am Main: Büchergilde Gutenberg, 1967), 197. 
and Joseph Langyel, who in 1926 were already starting to prepare for the League against Imperialism, which was launched at the International Congress against Colonial Oppression and Imperialism in Brussels in $1927 .{ }^{48}$ It is an educated guess that some of the European-looking faces against which there is a question mark are theirs. If this is correct, it would throw some light on the nature of Hamied's relationship with the Indian Bureau. He seems to have been familiar with the 'important people', even jotting down that Agnes Smedley was 'the famous communist', but later in life he could no longer recall the names of the more ordinary supporters.

The group photograph depicts the relationship between the Hindustan Association and the Indian Bureau at a specific moment in time, namely the first Eid festival after Zakir Husain left Germany. Hamied thought it appropriate to assemble ex-members of the Indian National Committee (M. Umar, Chatto, Tarachand Roy and Barakatullah), Indian students (Hasan, Shahidi, Malik and Nizamuddin), and European communists (Luba Derczanska, Agnes Smedley, Mrs Jacob, Sonia P/Frada, maybe also Louis Gibarti and Joseph Langyel) around the festival table. Question marks notwithstanding, it can be noted that around the table to celebrate the end of Ramadan is a mixed group of communists, their sympathizers, Hindus, Muslims, Indians, Europeans, men and women.

Is there someone in the photograph whose presence attests to a link with the pan-Islamist brethren in the Berlin Islamic Community? According to the organization's membership records, none of the people identified in the photograph had ever claimed to be a member. ${ }^{49}$ However, when, in June 1928, students in it challenged Abdul Jabbar Khairi's authoritarian, non-transparent leadership, Abdul Rauf Malik and the Hamied couple (Hamied had recently married Luba Derczanska in the Ahmadiyya mosque) were among the signatories. ${ }^{50}$ The example makes clear that the Indian Muslim-German network stretched and overlapped in every direction, but that foes did not necessarily invite each other.

Although no Ahmadiyya missionaries seem to have been invited, links to the Ahmadiyya mosque are easy to detect. An examination of the Moslemische Revue shows that, a year earlier, Khwaja Abdul Hamied, a well-versed Hafiz, had recited the Quran at the opening ceremony and that 'Professor Barakatullah, the famous Indian scholar' was among the distinguished speakers at the

48 Buber-Neumann, Von Potsdam nach Moskau, 102-7. Among the women collaborators she counted Agnes Smedley, Lucie Hecht and herself.

49 Register Office, VR B Rep. 042/N. 26590, 59-64.

5o Register Office Berlin-Charlottenburg, VR B Rep. 042/Nr. 26590, 30-47. 


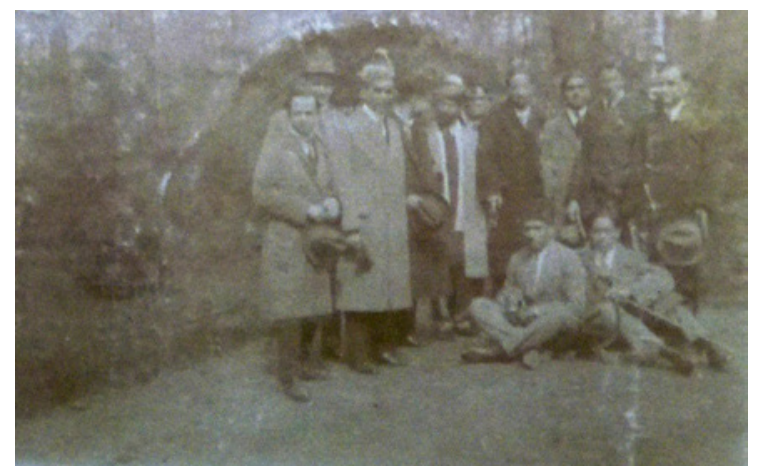

FIGURE 2.2

Ahmadiyya missionary Sadruddin at a meeting with the Indian Bureau, $c .1926$

mosque's 1926 Eid reception. ${ }^{51}$ The following pictures show that, among those who responded to Hamied's invitation, not only he and Barakatullah but also the Shahidi couple formed a bridge between the non-religious communists of the Indian Bureau and the religious intellectuals of this Muslim reform organization.

The above photograph is also from the Hamied album (Figure 2.2). It was of poor quality to begin with and has deteriorated over time, but it is still possible to discern 12 Indian men in their winter coats, hats in hand, with no women present. The artificial grotto behind them suggests that they are in one of the princely gardens surrounding Berlin, a popular tourist attraction even today. Khwaja Abdul Hamied (note the little beard that in his memoir he claimed to have shaved off in December 1926) poses in the centre. To his left we see Sadruddin, easily recognizable by his turban, which in Berlin was the hallmark of the Ahmadiyya missionary. To his right stands Chatto, recognizable by the typical slant of his head and the moustache that would soon become highly fashionable in Germany. These three men make up the centre of the group and the accompanying inscription reads 'Moulvi Sadruddin, Berlin 1926', suggesting that the gathering was to mark the occasion of receiving the missionary into their midst. ${ }^{52}$

Why did Hamied include this photograph in his gallery of recollections? The composition of the group suggests that it was he who introduced the Hindu leader of the Indian Bureau to the Muslim missionary. From its position in the album, tucked between several group photos of Indians (Muslims and Hindus), we may assume that this was a moment of some importance. Although a chemist by profession and more interested in securing a position in a German

$5^{1} \quad$ Moslemische Revue (1925/2) 1; Moslemische Revue (1926/2): 49.

$5^{2}$ Hamied private archive, photograph album, p. 6. Winter 1925 seems to be a more likely date. Zakir Husain is absent, but still wearing a beard. 
chemical plant than in the political in-fighting around him, Hamied was deeply interested in the German-Indian intellectual exchange and, like his friend Abid Hussain, attended Professor Spranger's lectures. The lessons he learned there about the German educational environment shaped both his professional and personal life. He must have detected that Chatto and Sadruddin had views in common, namely a belief in international brotherhood and the future of an Indian nation-state steeped in socialism. In his biography of Chatto, Nirode Barooah is clear that, though acting within a Bolshevist framework steered by Moscow, Chatto was in effect a nationalist rather than a communist. ${ }^{53}$ Starting from a different place, Sadruddin wrote articles that explored the connection between internationalism and international religion. What humanity really needed, he stressed, was a common bond that would enable everyone to have the same rights, duties and options. For this Ahmadiyya intellectual, there was not a shadow of doubt that this bond should be Islam. Whereas Europe was still pursuing the petty and small-minded aim of nationalism, Islam offered a model of universal mankind that allowed for brotherhood, justice, equality and democracy. ${ }^{54}$

These were lofty ideas, but this was a time and place in which many lofty ideas permeated the public discourse. The Indians in Berlin searched in every direction for ideas and allies to help them overcome the East-West divide with a view to embarking on a future together. Chatto developed models for a socialist nation-state that India might adopt after the war, while Sadruddin sought to introduce religion into the intellectual debate, which he saw as a stepping stone towards an internationalism that would encompass Hindus and Muslims alike.

We do not know what was said during that meeting, but it must have been important because, in the following years, the Indian Bureau and the Ahmadiyya community stabilized their relationship. Imam Khan Durrani, who in June 1926 came to replace Sadruddin, did not leave any private possessions from which to draw conclusions about his personal relationships with other Indians in Berlin, ${ }^{55}$ but he did, however, hand his address book over to his successor Abdullah. On his arrival in Berlin in June 1928, one of the first things this missionary organized was a get-together with Chatto. A snapshot commemorating

53 Barooah, Chatto, 157-77.

54 Sadruddin, 'Was hat der Islam der Menschheit gebracht?' Moslemische Revue, 1, (1925) 2-11. 


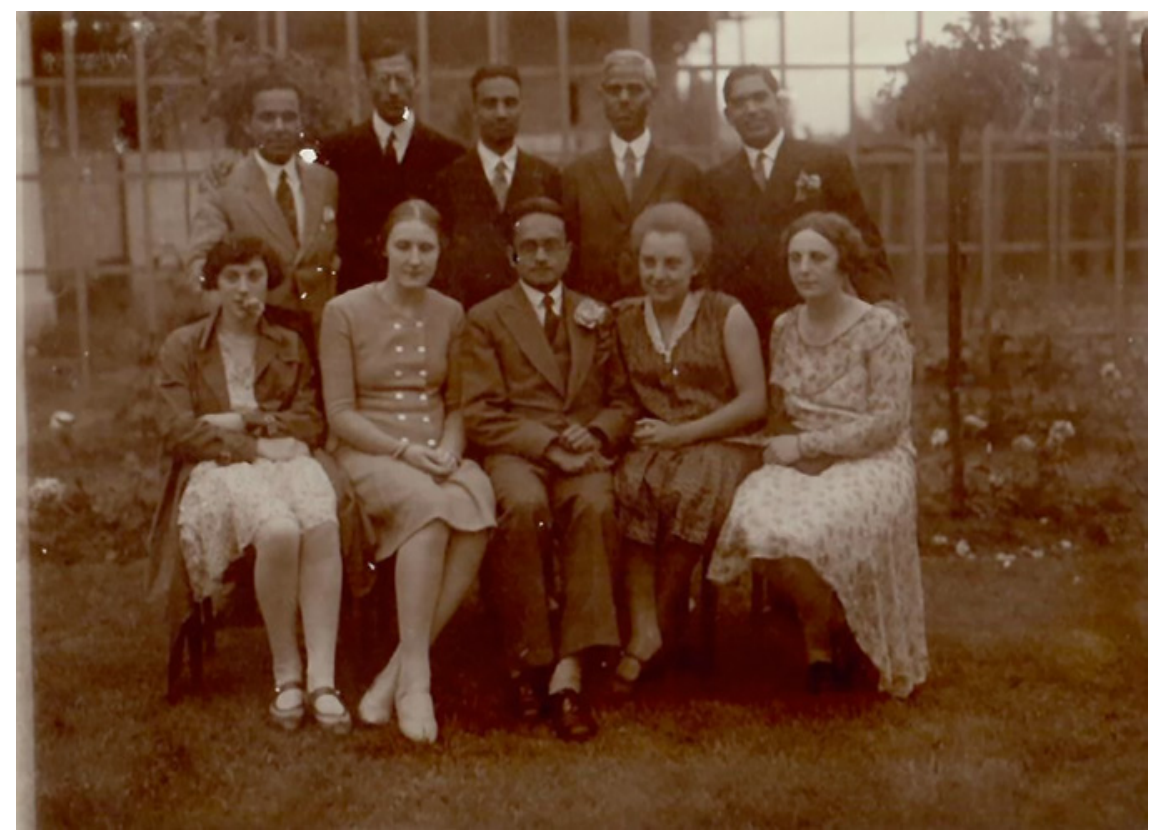

FIGURE 2.3 Indian-German couples in the mosque garden, c.1929

the occasion survives in Abdullah's private photograph album with a handwritten date, ' 6 July 1928' (Figure 2.3 ). ${ }^{56}$

Abdullah stands third from the left, an amiable Chatto at his side. The two men are surrounded by no less than four mixed couples. We recognize Shahidi standing on the far right, while his wife Hildegard Scharf, the one with the white frizzy hair, sits in front of him. Nizamuddin is the young man in the middle with the flower in his pocket. His fiancée, Estusia Tenenbaum, sits on the far left with a flower between her lips. Standing behind her is a man who often appears in the mosque photographs of this period. He could be M.A. Faruqui, a dedicated Ahmadi who explored the intellectual currents flowing between Islam and communism in the mosque's publications and who married a German woman. ${ }^{57}$ Until 1933, the couple attended every mosque event and came to the annual meetings of the German-Muslim Society. However, once the Nazis came to power, they left the country in a hurry, along with most other people who had openly sympathized with socialism or communism, and who had

$5^{6}$ Ahmadiyya Mosque archive, Berlin, photograph album, Abdullah.

57 His main publications are still in the mosque library. 


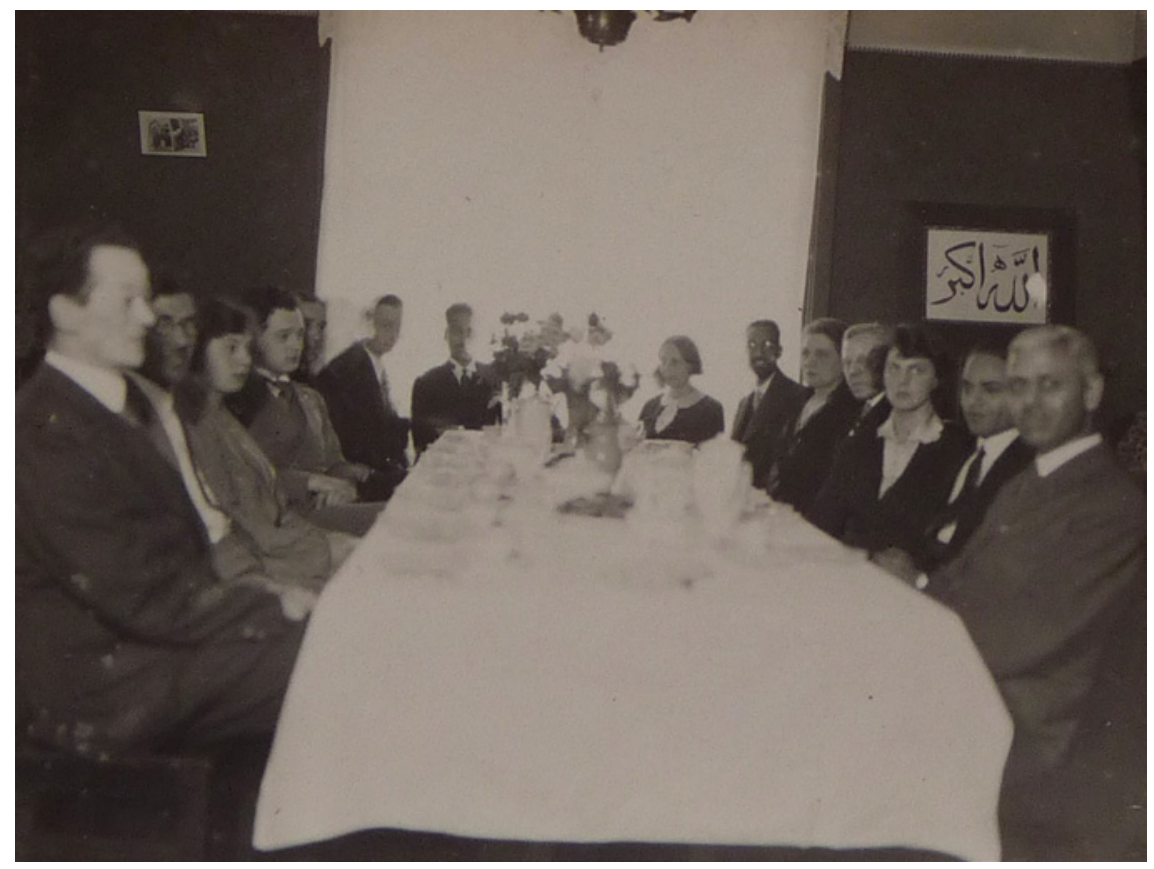

FIGURE 2.4 Eid al-Fitr at the mosque, 1929

expressed their ideas in the Weimar period. ${ }^{58}$ The album does not tell us why the group had gathered, but the venue (the mosque garden), everybody's fine clothes and the flowers all point to a wedding ceremony. Whether or not that was the case, it is nonetheless worth noting that the occasion called for the presence of V. Chattopadhyaya.

The last photograph to testify to the vibrant relationship between the Indian Bureau and the Ahmadiyya mosque was taken on the occasion of Eid 1929 (Figure 2.4). ${ }^{59}$ This time the venue is the mission house next to the mosque, featuring a table around which 14 people are assembled. It is only a wobbly shot, but we can discern Chatto sitting at the front of the table and facing Hugo Marcus, the imam's right-hand man and the main theorist of European Islam. Sitting next to them are two, yet unidentified, Indians. Behind them, Lisa Oettinger looks at the camera. Two places down we notice her mother Emilia Oettinger next to Abdullah, the one with the blinking spectacles. The woman at the far end of the table is Frau A. Faruqui. A festive flower arrangement almost hides her

$5^{8}$ The names of the fourth couple, the thin man with the spectacles and the woman in the buttoned dress, still await identification.

59 Ahmadiyya mosque archive, Berlin, photograph album Abdullah. 
husband from sight. In the middle of the table we still recognize Albert Seiler on the right, Susanna Oettinger, G. von Gutzkow and Werner Schubert on the left - all converts or enthused 'friends of Islam', whose faces are familiar from the pages of the mission journal.

Incidentally, the choice of guests suggests that the participants are celebrating yet another event. One month earlier, Hugo Marcus, Emilia Oettinger, G. von Gutzkow and Werner Schubert had set up a board to help Abdullah found the German-Muslim Society, the convert organization to promote Ahmadiyya ideas in interwar Berlin. The Faruquis, the Oettinger daughters and Seiler had been present to approve the board ${ }^{60}$ Who we perceive in the photograph then is the inner mosque community sitting around the Eid table. They have just agreed to shape a future in which Muslim and European traditions of intellectual exchange will be merged. Their tools are the reform of the self and the creation of a 'New Man', through which the 'religion of the future' will emerge. Again, any clue as to why they should invite Chatto is unavailable. All we can see is that he is sitting there, a comfortable smile on his face, witnessing the most significant moment in the history of the mosque.

\section{$5 \quad$ Lucie Hecht's Memories of the Indian Bureau}

First and foremost, the photographs reveal information about the Indians' network in Berlin, which, if anything, was characterized by fuzzy borders and the deliberate interference of Europeans. Furthermore, the photographs clarify that Jewish men and women joined them and, as the case studies show, Lisa Oettinger, Hugo Marcus and Luba Derczanska made further inroads. Now is the time to look at Lucie Hecht's involvement in the Indian Bureau. Glimpses of its inner workings, which Lucie shared with Horst Krüger in the 196os, help fill in some of the remaining blanks. By placing Lucie Hecht in her personal network, a tentative portrait is offered here.

Lucie Hecht(1898-1981) was the second child of a Jewish couple in PotsdamNowawes, a commuter town near the gates of Berlin. Her father Salo Ernst Hecht ran a medical practice for the poor, which enabled him to provide for his family and, at some point, even purchase a small villa. His wife Olga Löwenhain bore him three children. After the First World War, Lucie Hecht studied languages at Berlin University, but during the bank crash of 1923, she abandoned her studies to work as a short-hand typist to help support her family. By accident, she found a job in the Indian Bureau, about which she knew nothing.

60 Register Office Berlin-Charlottenburg, VR B Rep. 042/Nr 26590 (1922-1955), 1-10. 
As soon as she entered the premises, however, she became deeply involved in the Indian independence struggle. In her letters to Horst Krüger, she claims to have dealt with the translation work, helped organize the first Congress against Colonial Oppression and Imperialism in Brussels in 1927 and, after that event, became an ardent supporter of the League against Imperialism. Lucie was devoted to Chatto and stayed with him until the bureau was dissolved and he left for Moscow in 1932. Several sources claim that she had a romantic relationship with him. ${ }^{61}$

From her letters, it seems that she possessed a good measure of the romantic, revolutionizing zeal that Germans of the time reserved for Eastern peoples and their ideas. Full immersion in a movement that strove to rescue 'oppressed peoples' suited her admirably and to Krüger she wrote that she was 'electrified'. The letters still show some of the breathlessness with which she was propelled forward, doing secretarial work during the day, taking Chatto's dictation in the evening and translating deep into the night. ${ }^{62}$

Her description of 'the silent, isolated house, framed by pillars under a vaulted roof, with tall stained-glass windows through which the daylight broke and scattered'63 perfectly captures the mood of the Indian Bureau in BerlinHalensee. In her letters, she refers to Chatto as 'a magnetic personality', 'always on the road for India's freedom', and as its 'soul':

Chatto, himself a Hindu of the Brahmin caste, possessed little of the passivity and shy gentleness of the other Hindus, whose daily life was limited by strict regulations of an ethical-religious nature. ... He was actively 'fierce', always on the move, sparkling in his conviction, convincing because he lived, did, was, what he believed in. ${ }^{64}$

His vitality, Lucie Hecht writes, also attracted Muslim Indian students, 'first dozens of them, then by the hundreds'. ${ }^{65}$ Among them was Zakir Husain, who later became the president of India: he was 'an outstanding personality. He was

61 Barooah, Chatto, 214, 224; Price, The Lives of Agnes Smedley, 145, 451.

62 Lucie Hecht's private collection in the Horst Krüger papers, Box 33, 240-1, box 6o, 433-3. Their correspondence was conducted between 1967 and 1968 . It contains two letters from Krüger to Hecht, four letters ( 32 typed pages) from Hecht to Krüger, one letter from Hecht to Suhasini Chatto, a handful of photographs, and several documents.

63 Letter written between 24 April and 16 May 1967, 3.

64 Letter written between 24 April and 16 May 1967, 5 .

65 Letter written between 24 April and 16 May 1967, 5 . 
often in Halensee, arriving with that bold, lively step of the Mohammedans, towering above the tender, darker Hindu students with his fierce personality'.66

Her recollections of Zakir Husain and Chatto immersed in debate on the future of India summarizes her understanding of what stood at the core in Halensee:

In this struggle, Chatto, the 'warlike' Hindu, and Zakir Husain, the 'peaceful' Muslim, found one other. When standing together on the platform, deep in discussion, the unity between Hindus and Muslims was achieved at the highest possible level. How often Chatto would place his hand on Husain's shoulder as if he were knighting him or put his arm around him as if he were his son. ${ }^{67}$

To underline that dedication, she sent Krüger a photograph of Zakir Husain, taken in the Indian Bureau's garden in Halensee in 1925. It depicts a young man in Indian dress behind a spinning wheel, which was the symbol of Gandhi and Hindutva. Her byline runs: 'Zakir Husein - here behind the spinning wheel - as Gandhi's most loyal and devout disciple. An inspired personality, kind and gentle, deeply interested, thoughtful and taciturn most of the time, but full of inner fire' (Figure 2.5) ${ }^{68}$

The intensity of Lucie Hecht's dedication to the Indian cause was something that the Indians could not wholly comprehend. Muhammad Mujeeb, for instance, painted a portrait of her that conveys something of the cultural distance with which he encountered the German engagement:

Fraulein Hecht was a spinster of an uncertain age, but nearer forty than thirty. ... For me it was an act of courage to look at her, and I do not remember having ever spoken to her. But she was so utterly dedicated that she thought all the time of what she could do for Dr Zakir Husain. She translated his thesis and typed it for him, apart from other miscellaneous work. This was all she could do, but for her it was obviously not enough. ${ }^{69}$

Mujeeb penned those lines in the official biography of Zakir Husain, India's recently deceased president. Since the Zakir Husain Memorial Committee and

\footnotetext{
66 Letter written between 24 April and 16 May 1967, 5 .

67 Letter written between 24 April and 16 May 1967, 7 .

68 Letter written between 4 October 1967 and 3 February 1968. See Figure 2.5. Photograph in Horst Krüger papers, Box 33, 240-1.

69 Mujeeb, Dr Zakir Husain, 38.
} 


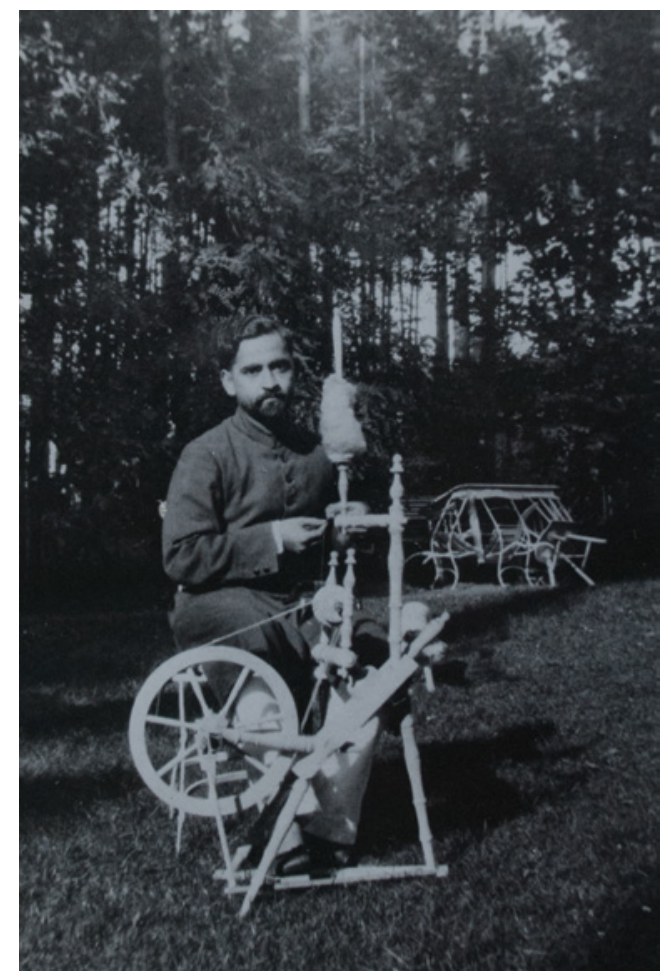

FIGURE 2.5

Zakir Husain behind the spinning wheel in Berlin-Halensee, $c .1925$

the minister of education commissioned him to write it, we may assume that his recollections were no mere slip of the tongue. ${ }^{70}$ His portrayal of Lucie Hecht may have been a standing joke among friends in Berlin, but putting it in the biography turned it into canonized knowledge. Mujeeb makes it acutely clear that Indian relationships with German women, whether Jewish or not, had their limits if the women's involvement was at stake. ${ }^{71}$

Through her attachment to the Indian Bureau and her translation work, Lucie Hecht related to a wide circle of people. Her personal network included the Chatto siblings Virendranath, Suhasini, Mrinalini, Harin and Saroyino Naidu; the Hindu poet and philosopher Rabindranath Tagore; Muslim Indian students such as Zakir Husain, Abid Hussain, Muhammad Mujeeb, Khwaja Abdul Hamied, Ishaq Shahidi and Ahmad Nizamuddin; the Indian political activists A.C.N. Nambiar, Rauf Malik and Mehdi Hassan; and the communists Karl

$70 \quad$ Mujeeb, Dr Zakir Husain, Preface.

71 Gerda Philipsborn's dedication to Zakir Husain and the Millia Jamia Islamia in Delhi seems to have posed another riddle. See Mujeeb, Dr Zakir Husain, 36-9, 54-5. 
Radek, Willi Münzenberg, Babette Gross and her sister Margarethe BuberNeumann, Agnes Smedley, Louis Gibarti and Professor Vladigerrow. ${ }^{72}$ Besides, she befriended the other Jewish women in the Indian Bureau, among them Luba Derczanska, Esther Tenenbaum, Sonia and Dunia P/Frada, and Gerda Philipsborn. ${ }^{73}$

The photographs in her collection make it plain that Lucie Hecht used to bring the Indians to her parents' home in Potsdam. Salo and Olga threw tea parties for them to which they also invited their Jewish neighbours. Their own circle included the staff of the Einstein Tower, the observatory in the 'Albert Einstein Science Park' not far from where the Hechts lived. Lucie befriended its director Erwin Finlay Freundlich and his wife Käthe Hirschberg. ${ }^{74}$ In the evenings, or so she notes, she often went over to do translation work for them. Her best friends, however, were the Chatto siblings. As she wrote in a letter to Krüger, whenever she went to the observatory on business calls, she used to tow them along with her. ${ }^{75}$

When examining Luba Derczanska's personal network in Chapter 6, we shall see that the two had many friends in common and that their personal networks partly overlapped. However, whereas Luba also befriended women from the mosque, Lucie Hecht's contacts with Muslims remained limited to the Indian Bureau. She appears in the photograph with the three JewishMuslim couples at a New Year dance in 1925 (Chapter 6), but in the iftar and related mosque photos, she is nowhere to be seen.

\section{Shared Goals}

To conclude this survey of the spaces in between, we must return once more to the web of contacts that was spun between the mosque and the Indian Bureau. What could a Muslim reform movement such as the Ahmadiyya offer to a Hindu nationalist like V. Chattopadhyaya that was valuable enough to sustain a relationship over many years? What tied the Indian Bureau to the mosque? The answer must be sought in the goals the two organizations held in common.

72 Their names and descriptions of them are scattered throughout her letters.

73 Luba Derczanska's correspondence in the Hamied private archive.

74 In her letter to Suhasini Chatto, she gives details of her parents' fate and that of their friends during the Nazi persecution. Letter dated 1o March 1967. Private collection of Lucie Hecht in the Horst Krüger papers.

75 One memorable photograph in the collection shows the whole group in the back garden of the Hecht mansion. Chatto is sitting next to Lucie and his siblings are lying down at their feet. 
There were basically three such goals. The first of these was student assistance. From the beginning, the Indian Bureau explicitly claimed that its raison deetre was to provide official papers, accommodation and an infrastructure for newly arriving Indian students. ${ }^{76}$ Roy even dourly suggested that Chatto could fix them up with doctoral degrees before they had even finished their studies. ${ }^{77}$ The circle in which the people in the Indian Bureau mixed consisted mainly of Indian students, students from eastern Europe and German communists.

The Lahore-Ahmadiyya mission also made it its business to reach out to students. It sought out young Germans in search of self-realization for which it offered them that rare mixture of individual piety and intellectualism that touched a raw nerve in postwar Germany. Their rapidly growing circle included students, artists and the highly fashionable life reformers. These were Germans who engaged in remodelling their lives along the principle of 'life reform', a form of individualization for which they used their bodies as an experimental field, which covered food, clothing, sexuality, body building and religion. It offered a point of entry through which Ahmadiyya intellectuals could introduce their central conviction, born of generations of Mughal aristocrats, that whoever wished to change the world should start by working on their own self. ${ }^{78}$

The second goal was cross-cultural marriage. The Ahmadiyya mosque explicitly addressed what other Indian organizations practised, namely the cross-cultural relationships blossoming almost everywhere. The mosque's imams, Sadruddin, Khan Durrani and Abdullah, each preached, lectured and wrote on gender relations and on the problems that cross-cultural relationships might bring. In fact, the mosque facilitated a large percentage of the cross-cultural marriages ${ }^{79}$ of couples who had met in either the Indian Bureau or the mosque. From the photographs, we know that Chatto's presence was required at quite a number of them.

The third and last goal was to do with visions of India's future. A group of young people who looked optimistically into a future together drifted between the Ahmadiyya mosque and the Indian Bureau, but their reasons for doing so varied. The Indians had come to Berlin on a mission to convert the Germans to their way of thinking, and the Germans had allowed themselves to be attracted by it. In this push-pull between India and Germany, the Indian nationalists developed visions of India's future; the Indian religious reformers envisaged a future in which the adherents of different religions would join hands; German

\footnotetext{
$76 \quad$ AA PA R $77 \cdot 461$ (29 December 1921).

77 Barooah, Chatto, 176.

78 Jonker, The Ahmadiyya Quest, 94-148.

79 The Ahmadiyya mosque archive contains hundreds of marriage certificates.
} 
bohemia contemplated 'wisdom from the East'; German women wanted independence while supporting the Indian cause; and German Jews sought to transcend their borders. In this mixture, India's future provided the screen onto which these people could project their very different dreams. For as long as none were realized, the boundaries between them would remain fuzzy.

In the chapters that follow, those common goals will resurface time and again. Here is the place to say that their fearless approach aptly illustrates the place of Indians in the Muslim-Jewish entanglement. Approaching the subject of cross-cultural and cross-religious bonding, and addressing the 'future man' this would engender, Indians opened up an in between space for downto-earth, everyday practices, of which the web of relations between the mosque and the Indian Bureau was just one.

In the interwar years, Berlin was a creative place to be. Until the Nazis came to power, the political future was still open for discussion and cross-cultural (emotional and intellectual) encounters bloomed. The unique approach of the Indian associations and organizations brought political activism, religious reform and secular practices into the equation without eroding intellectualism. The political and religious activism of the Indians forged connections between domains of knowledge and its transfer. The Lahore-Ahmadiyya mosque, in particular, provided South Asian Muslims with an intellectual space that paved the way for cross-cultural, even cross-religious, bonding. No wonder intellectuals like Chatto, who was neither a Muslim nor in any sense religious, but cared for Indians and the future of India, cherished the relationship.

This chapter has provided an introduction to Indian networking in interwar Berlin by offering an overview of the available primary sources. Scholars on Indians in Berlin have long studied Foreign Office records, but have so far ignored the religious files. The private archives introduced fresh information 'from below' into the text. It has been my aim to link the two sources of information public and private - to create a broader picture, one that addresses not only organizations and ideologies but also questions of who knew whom, how the network was wrought and how people located themselves within it.

In drawing this picture, the available sources did not necessary converge at pre-given points. For example, the Foreign Office surveillance of Indian organizations was purely from the point of view of security. Several government departments collected reports merely to show that they complied with governmental rules and regulations. The private archives, however, were on a very different footing, for the information they supplied tended to be highly 
subjective. The differences between the perspectives of outsiders and insiders are much like beams of light that keep missing each other, and it was only through studying the photographs that the links between the organizations and actors could be established.

Matching unknown faces to the names that appear in memoirs, on membership lists and in state archives is a daunting task. Nonetheless, it soon became apparent that state archives and private papers intertwine in interesting ways that have not yet been fully explored. To acquire a proper understanding of the Indian-Jewish networks that emerged in interwar Berlin, it is necessary to interrogate private and family archives and weave the stories they tell into the fabric of history writing. The five case studies that follow represent an attempt to undertake that task. 